Article

\title{
Implementation of E-Proctoring in Online Teaching: A Study about Motivational Factors
}

\author{
Carina S. González-González ${ }^{1, *} *$, Alfonso Infante-Moro ${ }^{2}\left(\mathbb{C}\right.$ and Juan C. Infante-Moro ${ }^{2}$ (C) \\ 1 Department of Computer Engineering and Systems, University of La Laguna, \\ 38200 San Cristóbal de La Laguna, Tenerife, Spain \\ 2 Department of Financial Economics, Accounting and Operations Management, University of Huelva, \\ 21071 Huelva, Spain; alfonso.infante@decd.uhu.es (A.I.-M.); juancarlos.infante@decd.uhu.es (J.C.I.-M.) \\ * Correspondence: carina.gonzalez@ull.edu.es
}

Received: 16 March 2020; Accepted: 21 April 2020; Published: 24 April 2020

\begin{abstract}
Most online teaching institutions still do not offer complete remote teaching, requiring the physical presence of the student in the evaluation process (for supervisory reasons), which could aggravate the evaluation and certification in massive open online teaching. Although, there are already e-proctoring tools (electronic proctoring) that allow this process to be carried out remotely, without requiring that physical presence. For this reason, and in order for this complete remote teaching to be extended to institutions that do not yet believe in the success of its implementation, this study, through a bibliographic study and a causal study carried out by experts in online teaching, focuses on locating the determining motivational factors when accepting and implementing this evaluation system as a method of remote supervision and tries to encourage its use through them. The list obtained consists of the following motivational factors: Quality management, available information, external conditioning, trust, perceived compatibility, perceived usefulness, attitude and intention, and the most decisive factor in this whole process is trust (which would be the extent of security and privacy that institutions have in the use of this tool).
\end{abstract}

Keywords: online teaching; remote teaching; e-proctoring; motivational factors; ICT; open education; education

\section{Introduction}

The online education system, which increasingly demands full remote teaching, continues to find its Achilles heel in the evaluation system. Nowadays, according the UNESCO Educational Disruption and Response to COVID-19 crisis, most governments around the world are closing the educational institutions and moving their activity to online and remote modality impacting over $89 \%$ of the world's student population. For example, in Spain, most universities have decided to move the exams in online modality. Thus, e-proctoring tools are very pertinent and significant supporting this process.

The e-proctoring (electronic proctoring) is a system formed by electronic tools that allows the monitoring of the remote evaluative process through telematic resources, trying to make the results reliable [1].

Despite the fact that there are already electronic proctoring tools that seek to guarantee the quality of the evaluation process without requiring the physical presence of the student in a specific place or the union of the student and the examiner in that place, e-proctoring still continues without widespread use in institutions.

Although a change in trend has been taking place with the appearance of massive online open courses (MOOCs) [2,3], is in open education in general and in online education in particular where e-proctoring is increasingly useful [4]. 
For this reason, and in order for this complete remote teaching to be extended to institutions that do not yet believe in the success of its implementation, this study focuses on locating the motivational factors determining the implementation of this evaluation system and seeks to promote its use through these. For this, a bibliographic study is carried out that allows a list of the most influential motivational factors to be exposed when accepting the use of new technological tools (that is, when the educational system accepts this tool as a method of remote supervision) and a causal map of the system is developed with them, in which experts in online teaching quantify and analyze the most influential factors when it comes to acceptance by educational institutions.

In data collection (for the construction of the causal map), the interview is used as an instrument, a causal map is made for each of the interviewees, and a global causal map is subsequently made with the average assessment of the experts, which allows its analysis through the FCMappers tool, which indicates the most influential factors, the factors that receive the most influence from the rest, and the most relevant factors within the system.

In the following section, electronic proctoring tools in educational institutions are contextualized through a literary review highlighting the situation of supervision in remote teaching, e-proctoring in the educational system is contextualized, and the most influential motivational factors in accepting the use of new technological tools are detailed. We continue with the methodology used in this study and the analysis of the results and conclude by pointing out the motivational factors determining the implementation of e-proctoring in online teaching.

\section{Literature Review}

When training processes are carried out in remote places, the presence of students and teachers or examiners who certify their knowledge becomes a problem.

In this context, trying to avoid this presence, most of the evolutions and changes have occurred in the teaching-learning processes [5-14], leaving the evaluation system relegated to physical presence in a specific place, for reasons of supervision. However, a point has been reached where the educational system and society demand tools that seek to ensure the quality of the evaluation process without necessarily requiring physical presence in a specific place.

This demand has led to the emergence of tools that allow monitoring this remote evaluation system through telematic resources [1], achieving e-proctoring in online teaching.

The e-proctoring is being used regularly in MOOCs, where online courses tried to impose themselves as substitute products for traditional teaching but found their main problem in the supervision of their evaluative tests for the subsequent certification of the knowledge achieved. As of today (since 2017), platforms such as edX (one of the main platforms in MOOCs) already use this methodology [15].

This proctoring method allows:

Visual and auditory surveillance, using the audio and cameras of the examinee's computer or mobile phone, as well as monitoring the computer, if the test is computerized (since it allows the option of taking computerized or paper-based exams). There are already many computer tools that allow viewing the computer screen where the student takes the test and, in addition, there are special browsers for e-proctoring that prevent the student from leaving the exam screen and only taking the test without consulting any other application or program on that computer. Systems such as Remote Proctor NOW (RPNOW), eProctoring, SMOWL or ProctorExams, use their own systems to ensure control of the computer on which the student performs the test.

This implies that the online educational system is greatly favored by its appearance, by allowing its evaluation process to be carried out remotely and the physical presence of the student in a specific place not being required.

However, its advantages are not included in this alone, since the use of this tool also allows the adaptability of the exams to define the level of the student on a scale, such as that of the European Framework of Reference for Languages or in Adaptive Tests [16]. 
This tool has more and more applications, in fields as diverse as in online personnel recruitment, where it is used more and more frequent [17], and in virtual campuses, where it is growing exponentially [18].

Likewise, its use is growing greatly in geographically dispersed territories and in emerging countries (offering opportunities for complete remote training) [19,20], in new forms of teaching augmented reality in engineering studies [21], in asynchronous environments within the teaching-learning processes [22,23], in new forms of education such as MOOCs or microdegrees (providing credibility in the identification when evaluating and certifying knowledge) [15], and in the evaluation and certification of competencies to practice professions (as is done at the International Accrediting Body [24] and at Indiana University [25,26]).

E-proctoring is going to end up prevailing in online teaching, but it is true that there are problems when the exams are not well prepared to be carried out under this modality or when vigilantes or examiners do not know how to act when problems arise regarding the reaction of the student or problems in telematic communication. This has led to the development of mathematical models and algorithms to improve the behavior of those who design the exams when taking them and of those who monitor these exams [27-30], in the interest of improving the e-proctoring system.

Despite the aforementioned information and that ProctorU (one of the most common Proctoring systems currently) announced in 2017 that it had already carried out more than 4 million exams by this procedure [31], many of the online teaching institutions do not implement this tool in their evaluation system. Thus, this study seeks to find what are the motivational factors responsible for this.

To do this, a bibliographic study is first carried out to create a list of the most influential motivational factors when accepting the use of new technological tools, searching scientific databases and reviewing those scientific articles that related variables and motivational factors with the use of technological tools (such as the article by Sánchez-Prieto, Huang, Olmos-Migueláñez, García-Peñalvo and Teo [32]), and finally collecting the distribution that the author R. Arteaga [33] makes in her study after an extensive literary review by experts in this field (Table 1). This list is made up of the following factors: Quality management $(\mathrm{QM})$, available information (AI), external conditioning (EC), trust (T), perceived compatibility (PC), perceived usefulness (PU), attitude (A), and intention (I).

Table 1. Most influential motivational factors when accepting the use of new technological tools.

$$
\text { Quality Management (QM) }
$$

This factor would be the extent of satisfaction when using a new technological tool, but only in terms of whether quality is perceived in its use [34] and whether it provides demonstrable and tangible results [35-37]

$$
\text { Available Information (AI) }
$$

This factor would be the tendency to adopt and use a new technological tool with the available information [38].

$$
\text { External Conditioning (EC) }
$$

This factor would be the influence that potential users receive from the environment to use a new technological tool. This influence can be positive or negative, and some examples of these external conditioning factors can be seen in the comments or suggestions of important people for the user and in the help that is found to learn how this new tool works [39-41].

\section{Trust (T)}

This factor would be the extent of security and privacy that users of a new technological tool expect to have when using it [42-44].

Perceived Compatibility $(P C)$

This factor would be the extent of perception of compatibility of a technological product by the user, based on their values and personality [36,45]. Studies such as Tan and Teo's [46] confirm that perceived compatibility influences users when adopting and motivating the use of technological products. 
Table 1. Cont.

\begin{tabular}{|c|}
\hline Perceived Usefulness (PU) \\
\hline $\begin{array}{l}\text { This factor would be the perception that the use of a technological product would increase the } \\
\text { performance of its user [47]. Studies such as that of Chiu, Lin, and Tang [48] or that of Nysveen, } \\
\text { Pedersen, and Thornbjørnsen [49] confirm that perceived utility influences users when adopting } \\
\text { and motivating the use of technological products. All of this depending on whether this use } \\
\text { helps to achieve the expected task and whether its use provides advantages over the traditional } \\
\text { method [50,51]. }\end{array}$ \\
\hline Attitude (A) \\
\hline $\begin{array}{l}\text { This factor would be the perception of a user about whether a new technological tool favors the } \\
\text { behavior it performs or not [52]. Studies such as that of Ajzen and Fishbein [53] confirm that the } \\
\text { attitude influences the behavior of users when adopting and motivating the use of any product. }\end{array}$ \\
\hline Intention (I) \\
\hline $\begin{array}{l}\text { This factor would be the motivational elements that make a user use a new technological tool or } \\
\text { not [48]. Studies such as that of Taylor and Todd [54] or that of Ajzen [52] confirm that intention } \\
\text { influences the behavior of users when adopting and motivating the use of any product. }\end{array}$ \\
\hline
\end{tabular}

This distribution is the axis of distribution of the results of the study carried out to the experts in online teaching below, which tries to locate the motivational factors determining the implementation of e-proctoring in online teaching.

\section{Methodology}

The model used in this study was the fuzzy cognitive maps (FCMs), a method that facilitates the visualization of a network of concepts and systemic factors linked by cause-effect relations of semantic nature $[55,56]$.

The fuzzy cognitive maps (FCMs) methodology is one of the most relevant in the study of knowledge and, probably, one of the most used in recent times by researchers in their studies and projects [57]. They are a tool that can be used in different situations or problems to identify, define, and validate the constructs or elements of a system and identify the cause-effect relationships that exist between them, in order to propose strategies and help in decision-making [58]. In addition, they are able to anticipate possible new changes due to changes in the behavior of some of these constructs.

Thus, in the scientific field, it is used for the following applications: Descriptive (to describe a system, with the elements or agents involved in that system), explanatory (to explain the behavior of the elements or agents involved in a system), reflective (to make decisions, as an instrument to support decision-making), and/or predictive (to predict the actions of the elements or agents involved in a system) [59].

Thus, the use of this model in this study allows confirming or ruling out the influence of motivational factors that are obtained after the literary review by previous studies on the factors that influence when the educational system accepts this tool as a method of remote online supervision. In addition, it allows determining whether there is an influence between each of the factors that belong to said system and knowing the degrees of all these influences.

Once the factors that make up this system have been found and selected (exposed in the literary review), we proceeded to obtain the data and information on the extent of influences between them. For this, the experts in online teaching (people know the most influential motivational factors determining whether the educational system accepts this tool as a method of remote supervision) were selected as the "Population" object of study, and the sample size was fixed by the use of cumulative graphs of the number of new influencing factors with respect to the number of individuals belonging to the sampled interest group, as suggested by U. Özesmy and S. L. Özesmy [60] for this type of study based on fuzzy cognitive maps (FCMs). In this case, the sample was made up of 8 experts (since none added new influencing factors) (Figure 1). These experts in online teaching are international university 
professors with training in information and communication technologies (ICTs) and knowledge of how to apply technologies in a useful and effective way for the student, who teach or have taught in virtual and face-to-face universities (for which they know the strengths and weaknesses of these two types of institutions), hold a doctor's degree, and among their lines of research are the information and communication technologies in teaching, in online teaching, and in educational institutions. Another requirement that was taken into account when selecting these experts is that they be professionals with knowledge about what new learning methods and techniques are being implemented and what effects they may have on students.

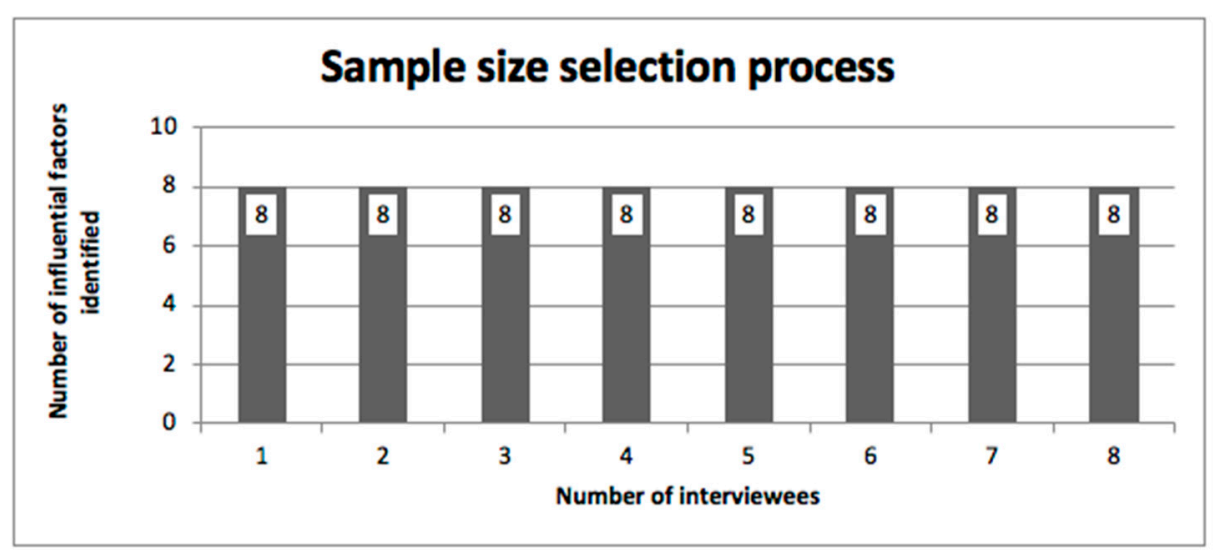

Figure 1. Sample size selection process.

The instrument used to obtain this data and information from the users who make up the sample was the interview, although it is desirable in this method that each of the people who make up the sample to be analyzed draw a picture of the conceptual network of the system to be studied. Even so, this model is also allowed to obtain this information through questionnaires or interviews [60]. The interview facilitates obtaining the necessary information and ensures much information is not omitted due to the time and effort in drawing the graph of the conceptual network by the people who constitute the sample.

This interview was carried out in order to know the opinion of the interviewees on the motivational factors that influence when the educational system accepts and implements e-proctoring as a method of remote supervision in online teaching and on the degree of influences that these motivational factors exert on each other.

At the beginning of each interview, and as was done in the study of J. Solana [61] in which the fuzzy cognitive maps (FCMs) were used as technical study, each respondent received a template with the factors of this system, which served as a guide for the interviewees (Table 2). In this way, it was intended to get the interviewees to take this list of motivational factors and give the causal connections that exist between them. In addition, they provided, if they saw fit, new motivational factors.

Table 2. Motivational factors: concepts components of this fuzzy cognitive map (FCM).

\begin{tabular}{ccc}
\hline Variable & Definition & Keywords \\
\hline QUALITY MANAGEMENT & $\begin{array}{c}\text { The extent of satisfaction when using a new technological tool, } \\
\text { but only in terms of whether quality is perceived in its use and } \\
\text { whether it provides demonstrable and tangible results. } \\
\text { The tendency to adopt and use a new technological tool with } \\
\text { the available information. }\end{array}$ & $\begin{array}{c}\text { Qualiable information } \\
\text { on its use } \\
\text { EXTERNAL CONDITIONING }\end{array}$ \\
TRUST & $\begin{array}{c}\text { The influence that potential users receive from the } \\
\text { environment to use a new technological tool. } \\
\text { The degree of security and privacy that users of a new } \\
\text { technological tool expect to have when using it. }\end{array}$ & Trust \\
\hline
\end{tabular}


Table 2. Cont.

\begin{tabular}{ccc}
\hline Variable & Definition & Keywords \\
\hline PERCEIVED COMPATIBILITY & $\begin{array}{c}\text { The extent of perception of compatibility of a technological } \\
\text { product by the user, based on their values and personality. } \\
\text { The perception that the use of a technological product would } \\
\text { increase the performance of its user. }\end{array}$ & $\begin{array}{c}\text { Compatibility with } \\
\text { your activity } \\
\text { PERCEIVED USEFULNESS }\end{array}$ \\
$\begin{array}{c}\text { The perception of a user about whether a new technological } \\
\text { tool favors the behavior it performs or not. }\end{array}$ & Attitude \\
ATTITUDE & $\begin{array}{c}\text { The existence of motivational elements that make a user use a } \\
\text { new technological tool or not. }\end{array}$ & Intention \\
\hline
\end{tabular}

However, this was not the only table given to the interviewees at the beginning of each of the interviews, since it was not only necessary for this study to know whether or not these causal relationships exist, but also to know the extent of them. For this reason, they also received a semantic evaluation table, the semantic graduation of the connections of which were set according to the extent of causal influence that each of the interviewees thinks that one variable may have on another, and whether that influence is positive or negative [62] (Table 3).

Table 3. Semantic assessment table: interpretation of cause-effect relationships.

\begin{tabular}{cc}
\hline Value & Semantic Relation \\
\hline 1 & Very strong positive \\
0.9 & \\
0.8 & Strong positive \\
0.7 & \\
0.6 & Medium positive \\
0.5 & \\
0.4 & Weak positive \\
0.3 & \\
0.2 & Very weak positive \\
0.1 & \\
0 & There is no relationship \\
-0.1 & \\
-0.2 & Very weak negative \\
-0.3 & \\
-0.4 & Weak negative \\
-0.5 & \\
-0.6 & Medium negative \\
-0.7 & \\
-0.8 & Strong negative \\
-0.9 & \\
-1 & Very strong negative \\
\hline
\end{tabular}

After obtaining the data from the interviews, on the existence or not of causal relationships between the proposed concepts, an adjacency matrix was constructed per interviewee that simulated the cause-effect unions between the concepts, formed by values of the interval $[-1,1]$ [63]. Subsequently, all these adjacent matrices or fuzzy cognitive maps (FCMs) were combined into a single matrix or collective map, in which the individual matrices were assigned to each concept. Through this, the extent of influence of these variables was obtained in the implementation of e-proctoring as a method of remote supervision in online teaching, the system variables were classified according to their influence on the other variables, and the indicators were obtained in terms of outdegree, indegree, and centrality, thanks to the FCMappers software [64].

\section{Results}

The modeling of the collective cognitive matrix or collective map based on the influences between the various motivational factors was obtained from eight matrices corresponding to eight experts 
who were interviewed. This matrix was formed by eight motivational factors and, in turn, 54 causal connections as can be seen in the following table (Table 4).

Table 4. Adjacent matrix of the collective fuzzy cognitive map (FCM).

\begin{tabular}{|c|c|c|c|c|c|c|c|c|}
\hline & 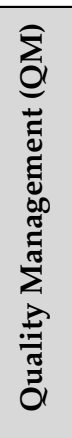 & 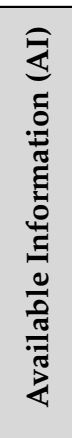 & 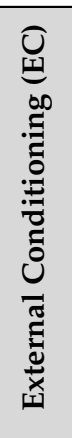 & $\underset{\frac{\hbar}{D}}{E}$ & 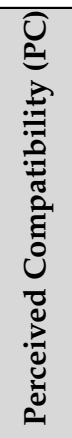 & 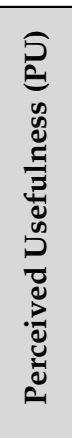 & 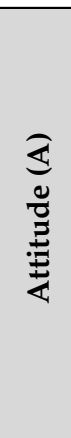 & 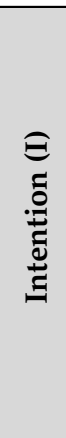 \\
\hline Quality Management (QM) & & 0.70 & 0.70 & 0.90 & 0.70 & 0.30 & 0.90 & 0.90 \\
\hline Available Information (AI) & 0.30 & & 0.50 & 0.90 & 0.64 & 0.80 & 0.82 & 0.90 \\
\hline External Conditioning (EC) & 0 & 0.70 & & 0.90 & 0.35 & 0.40 & 0.63 & 0.58 \\
\hline Trust (T) & 0.20 & 0.60 & 0.80 & & 0.41 & 0.41 & 0.90 & 0.90 \\
\hline Perceived Compatibility (PC) & 0.60 & 0 & 0.60 & 0.80 & & 0.80 & 0.90 & 0.90 \\
\hline Perceived Usefulness (PU) & 0.30 & 0.80 & 0.70 & 0.90 & 0.70 & & 0.90 & 0.90 \\
\hline Attitude (A) & 0.40 & 0.70 & 0.70 & 0.80 & 0.60 & 0.60 & & 0.72 \\
\hline Intention (I) & 0.25 & 0.70 & 0.70 & 0.80 & 0.50 & 0.34 & 0.64 & \\
\hline
\end{tabular}

In this fuzzy cognitive map (FCM), the extent of influence between these factors make these variables or factors of an ordinary type; that is, each of these factors exerts and receives influences from the other factors.

The analysis of this matrix with the FCMappers software allows analyzing the structure of this fuzzy cognitive map (FCM) through three indicators [65]:

The "outdegree" indicator, which is the sum of the values of the adjacent matrix associated with the connectors that come out of a node or variable. A transmitting variable has a high outdegree.

The "indegree" indicator, which is the sum of the values of the adjacent matrix associated with the connections that enter a node, which shows the extent of dependency of the variable. A receiving variable has a high indegree.

The "centrality" indicator, which is the sum of the outdegree and indegree indicators, and indicates the extent of participation or importance of the variable in the system.

Thus, the most important variables of this cognitive map are those that have high centrality values, since they regulate the dynamics of the system [60] (Figure 2). 


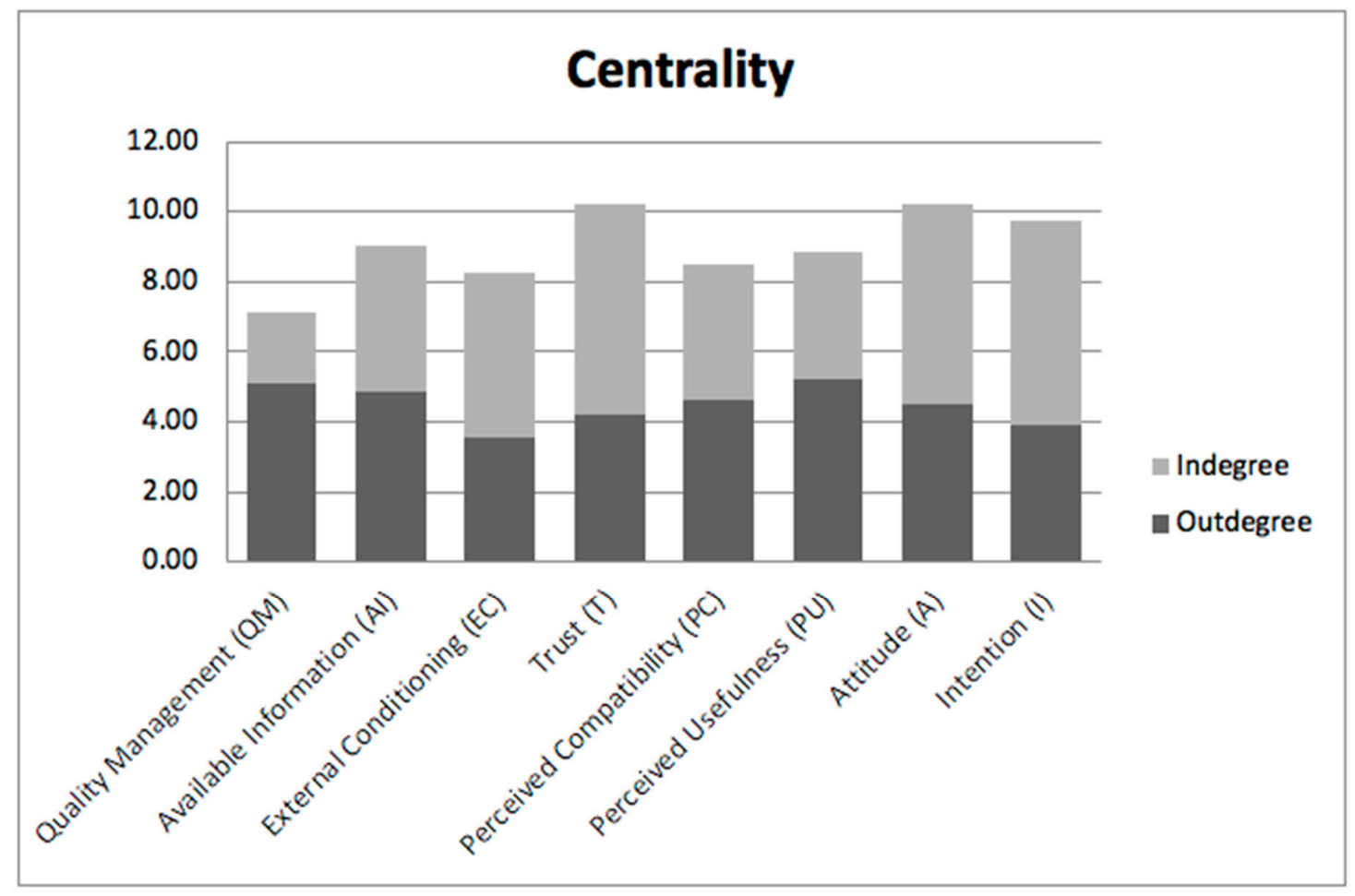

Figure 2. Indicators of the fuzzy cognitive map (FCM): Centrality.

The difference between the outdegree and the indegree of a variable indicates the type of variable that is observed: The variables that have high outdegree values strongly influence the rest of the concepts (perceived usefulness, quality management, and available information), and the variables with high indegree values are strongly influenced and dependent on the rest of the concepts (trust, intention, and attitude) (Figures 3 and 4).

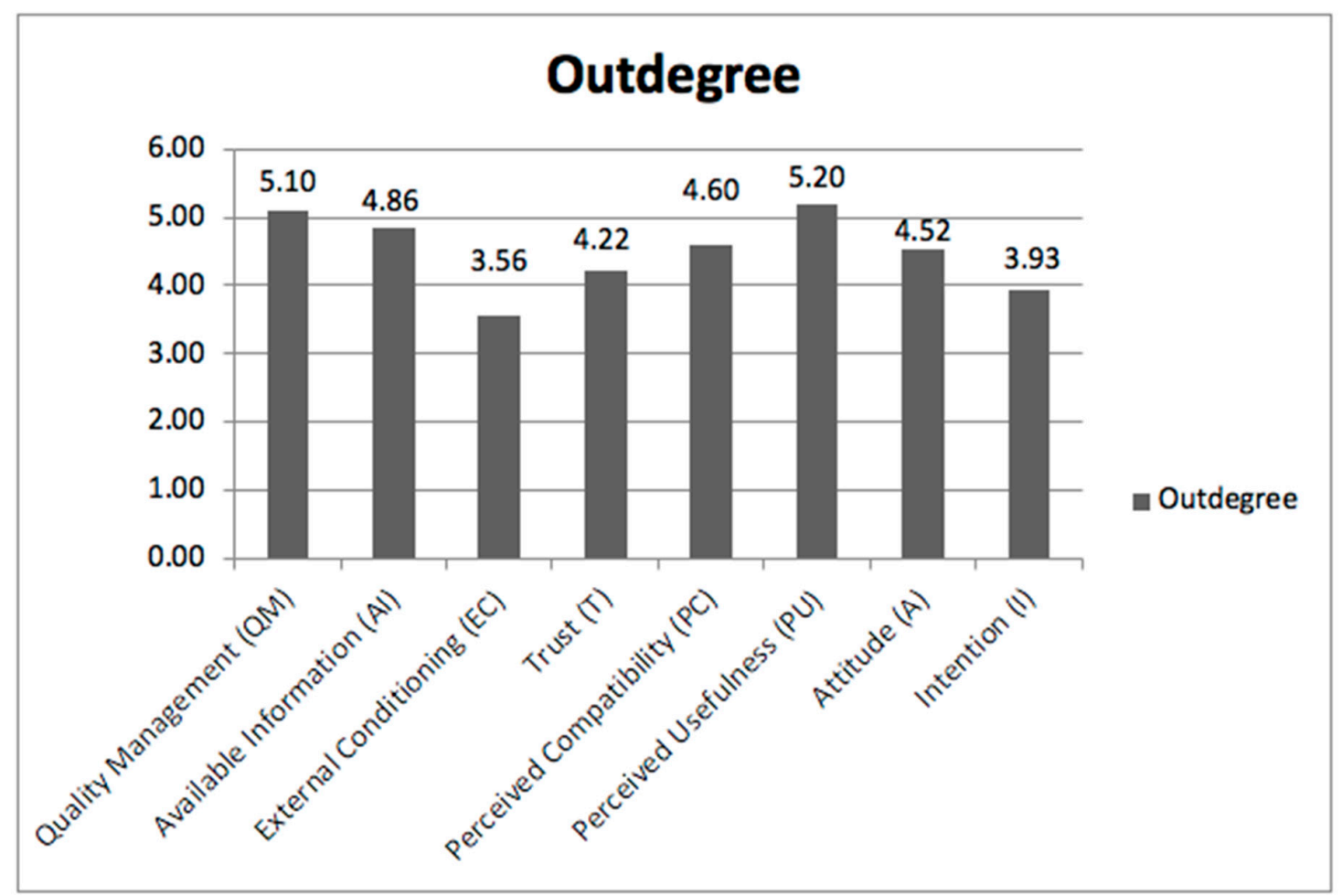

Figure 3. Indicators of the fuzzy cognitive map (FCM): Outdegree. 


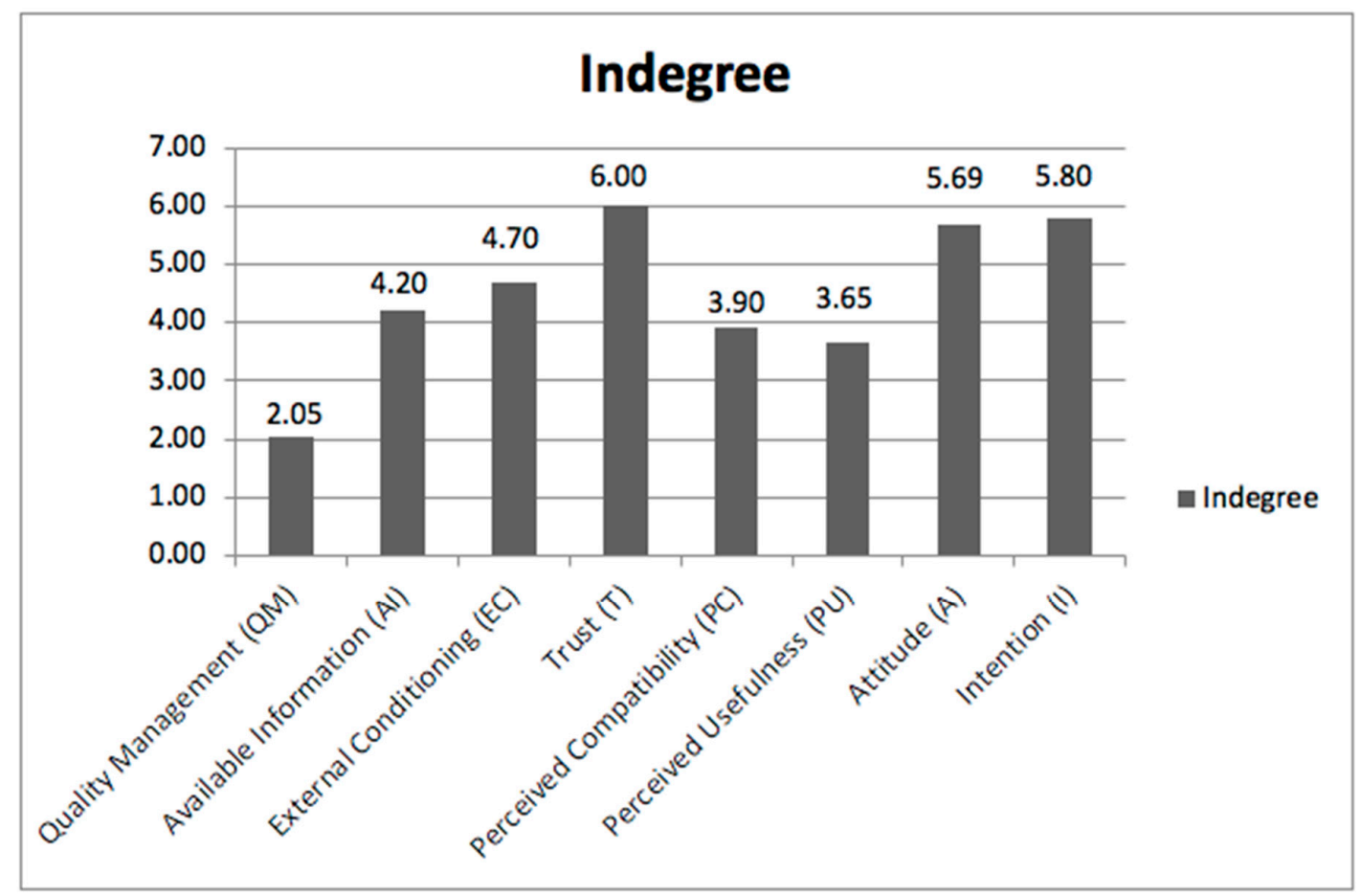

Figure 4. Indicators of the fuzzy cognitive map (FCM): Indegree.

With all this, the variables or factors with greater centrality, outdegree, and indegree are shown in the following table (Table 5).

Table 5. Variables with higher centrality, outdegree and indegree indicators.

\begin{tabular}{ccc}
\hline Centrality & Outdegree & Indegree \\
\hline Trust (T) & Perceived Usefulness (PU) & Trust (T) \\
\hline Attitude (A) & Quality Management (QM) & Intention (I) \\
\hline Intention (I) & Available Information (AI) & Attitude (A) \\
\hline
\end{tabular}

The variable with the greatest centrality was trust $(T)$, which was the sixth most influential in the rest of the variables (outdegree $=4.22$ ) and the most dependent on the other variables (indegree $=6.00$ ). The variable with the least centrality was quality management (QM), which was the one with the second highest extent of outdegree and the one with the lowest extent of indegree. The main variables ordered according to the centrality indicator are shown in Figure 2.

The variables that exerted the most influence on the other variables were: Perceived usefulness (PU), quality management (QM), and available information (AI). The most dependent variables were: Trust (T), intention (I) and attitude (A). The main variables ordered according to the outdegree and indegree indicators are shown in Figures 3 and 4.

With that, in general lines, it can be said that a system was observed in which the factors that exert the most influence on the rest of the factors were those that came from the users' own vision (perceived usefulness and quality management), while the factor that received more influence from the rest was trust. Also, a system in which intention and attitude were obviously dependent on the other factors (two of the three most dependent) was observed, since they were the closest step to its use. Lastly, we observed a system in which trust, despite being one of the least influences on the rest, was the most important factor in the system (due to the influences it receives from the rest of the factors) when the educational system accepts and implement e-proctoring as a method of remote supervision in online teaching. 


\section{Conclusions}

Online teaching still does not offer complete remote teaching in most cases, since there are many institutions that, in the evaluation process, continue to require the physical presence of the student in a specific place to unite the student and the examiner in said place, for supervisory reasons. However, there are already e-proctoring tools that allow this process to be carried out remotely, without requiring that physical presence. Additionally, there is a favorable trend in the application of this methodology in MOOCs and in open education globally.

Thus, this study has sought to locate the motivational factors determining the implementation of this evaluation system, allowing the exposition of a list of motivational influencing factors when accepting the use of new technological tools (that is, when the educational system accepts this tool as a method of remote supervision), and determine which are the most influential or decisive when it comes to acceptance by educational institutions.

The list is made up of the following motivational factors: Quality management (QM), available information (AI), external conditioning (EC), trust (T), perceived compatibility (PC), perceived usefulness (PU), attitude (A) and intention (I). The most decisive factor in this process is trust (T), which would be the degree of security and privacy that institutions have in the use of this tool (e-proctoring).

This coincides with the main line of research on this tool, where most of the studies focus on trust and the safety of using it. Something that can be seen in studies from years ago, as can be seen in Howlett and Hewett [66], is that both technological solutions and instructional design solutions to reduce cheating in these remote examinations were already examined.

However, this has not changed, and to this day the research continues in the same direction $[67,68]$ despite the good functioning of the examples that were shown in the literary review and that studies such as those of Atoum, Chen, Liu, Hsu, and Liu [69], Davis, Rand, and Seay [70], OReilly and Creagh [71], and Kayser [72], stress the trust and security in e-proctoring, and recommend its use to online educational institutions (and even in place of face-to-face).

This means that the distributors of these types of tools must carry out good communication and advertising campaign regarding the security and privacy of this tool if they want to conquer and consolidate its use in online teaching institutions. Not only that, they must also encourage and incentivize the rest of the motivational factors since the trust factor receives the most influence from the rest of the factors.

For this reason, in this campaign, they must also offer adequate prior information to these institutions, since many are not aware of its characteristics (available information), the benefits of its use (perceived usefulness), compatibility with its type of business (perceived compatibility), and effectiveness and quality with demonstrable results (quality management). In addition, they must request their clients to advertise their use of this tool, so that they can serve as an example to other institutions (external conditioning).

The other two factors (attitude and intention), being two of the three factors most dependent on the rest, also owe their importance within the system and their extent of influence on the other factors.

Thus, in general terms, it can be said that this is intended to change the vision of institutions dedicated to online teaching regarding e-proctoring and to encourage the use of this tool in their institutions, allowing complete remote teaching, which is what the online educational system demands.

This research is limited to the study of motivational factors in the implementation of e-proctoring in educational institutions, but this limitation can be eliminated in future studies and extend this study to other types of factors that also influence this implementation, such as the study of the weaknesses of the different technological tools used by this remote supervision system.

Author Contributions: Conceptualization, methodology, software, formal analysis, investigation, resources, data curation, writing - original draft preparation, validation, writing - review and editing, visualization, supervision, and project administration, C.S.G.-G., A.I.-M., and J.C.I.-M. All authors have read and agreed to the published version of the manuscript. 
Funding: This research received no external funding.

Conflicts of Interest: The authors declare no conflict of interest.

\section{References}

1. Pathak, B.K. Emerging online educational models and the transformation of traditional universities. Electron. Mark. 2016, 26, 315-321. [CrossRef]

2. García-Peñalvo, F.J.; Fidalgo-Blanco, Á.; Sein-Echaluce, M.L. An adaptive hybrid MOOC model: Disrupting the MOOC concept in higher education. Telemat. Inform. 2018, 35, 1018-1030. [CrossRef]

3. Beltrán Hernández de Galindo, M.; Ramírez-Montoya, M. Innovación en el diseño instruccional de cursos masivos abiertos (MOOC's) para desarrollar competencias de emprendimiento en sustentabilidad energética. Educ. Knowl. Soc. 2019, 20, 15. [CrossRef]

4. García-Peñalvo, F.J. Modelo de referencia para la enseñanza no presencial en universidades presenciales. Campus Virtuales 2020, 9, 41-56.

5. Mato-Vázquez, D.; Álvarez-Seoane, D. La implementación de TIC y MDD en la práctica docente de Educación Primaria. Campus Virtuales 2019, 8, 73-84.

6. Infante-Moro, A.; Infante-Moro, J.C.; Gallardo-Pérez, J. The Importance of ICTs for Students as a Competence for their Future Professional Performance: The Case of the Faculty of Business Studies and Tourism of the University of Huelva. J. New Approaches Educ. Res. 2019, 8, 201-213. [CrossRef]

7. López Belmonte, J.; Pozo Sánchez, S.; Vicente Bújez, M.R.; Díaz Mohedo, M.T. Herramientas robóticas para la dinamización de nuevos espacios educativos. Campus Virtuales 2019, 8, 63-73.

8. Morales Salas, R.E.; Infante-Moro, J.C.; Gallardo-Pérez, J. La mediación e interacción en un AVA para la gestión eficaz en el aprendizaje virtual. Campus Virtuales 2019, 8, 49-61.

9. Rey Castillo, M.; Gómez Zermeño, M.G. Tendencias en investigación sobre Learning Management Systems. Int. J. Inf. Syst. Softw. Eng. Big Co. 2019, 6, 123-134.

10. González-González, C.S.; Guzmán-Franco, M.D.; Infante-Moro, A. Tangible Technologies for Childhood Education: A Systematic Review. Sustainability 2019, 11, 2910. [CrossRef]

11. De la Serna-Tuya, A.S.; González-Calleros, J.M.; Navarro, Y. Las Tecnológicas de Información y Comunicación en el preescolar: Una revisión bibliográfica. Campus Virtuales 2018, 7, 19-31.

12. González González, C.S.; Herrera González, E.; Moreno Ruiz, L.; Reyes Alonso, N.; Hernández Morales, S.; Guzmán Franco, M.D.; Infante Moro, A. Computational Thinking and Down Syndrome: An Exploratory Study Using the KIBO Robot. Informatics 2019, 6, 25. [CrossRef]

13. Mena Guacas, A.F.; Santoveña Casal, S.M. Whatsapp and Formulating Guidelines on Network Interaction during the Learning Process in the University Classroom. Int. J. Educ. Res. Innov. 2018, 13, 121-136.

14. Infante-Moro, A.; Infante-Moro, J.C.; Torres-Díaz, J.C.; Martínez-López, F.J. Los MOOC como sistema de aprendizaje en la Universidad de Huelva (UHU). Ijeri: Int. J. Educ. Res. Innov. 2017, 7, 13-24.

15. EdX. Online Proctoring Pioneer Joins Open edX Platform to Ensure Integrity of Online Testing. PR Newswire, 20 July 2017.

16. Kantrowitz, T.M.; Dawson, C.R.; Fetzer, M.S. Computer adaptive testing (CAT): A faster, smarter, and more secure approach to pre-employment testing. J. Bus. Psychol. 2011, 26, 227-232. [CrossRef]

17. Behrend, T.S. Online recruiting and selection: Innovations in talent acquisition. Pers. Psychol. 2010, 63, 804-806.

18. Dew, J. Global, mobile, virtual, and social: The college campus of tomorrow. Futurist 2010, 44, 46-50.

19. Blimpo, M.P. Team incentives for education in developing countries: A randomized field experiment in benin. Am. Econ. J. Appl. Econ. 2014, 6, 90-109. [CrossRef]

20. Mujtaba, B.G.; Afza, T. Virtual leaps in distance education: A conversation with dr. naveed A. malik, founding rector of the virtual university of pakistan. J. Appl. Manag. Entrep. 2013, 18, 113-122. [CrossRef]

21. Shanbari, H.; Blinn, N.; Issa, R.R.A. Using augmented reality video in enhancing masonry and roof component comprehension for construction management students. Eng. Constr. Archit. Manag. 2016, 23, 765-781. [CrossRef]

22. Wagner, E.; Enders, J.; Pirie, M.; Thomas, D. Supporting academic integrity in a fully-online degree completion program through the use of synchronous video conferences. J. Inf. Syst. Educ. 2016, 27, 159-173. 
23. Hilgers, M.G.; Flachsbart, B.B.; Elrod, C.C. Collaborative international education: Reaching across borders. Multicult. Educ. Technol. J. 2012, 6, 45-56. [CrossRef]

24. International Accrediting Body. International Accrediting Body for first time, approves online proctoring of critical examinations. PR Newswire, 7 December 2017.

25. Indiana University. Indiana University selects proctoring platform to ensure integrity of online assessments. PR Newswire, 6 December 2017.

26. Arbués, E. El desarrollo de competencias en el alumnado universitario. Nuevos retos metodológicos. Certiuni J. 2016, 2, 10-18.

27. Navarro, P. How economics faculty can survive (and perhaps thrive) in a brave new online world. J. Econ. Perspect. 2015, 29, 155-176. [CrossRef]

28. Collins, D.; Weber, J.; Zambrano, R. Teaching business ethics online: Perspectives on course design, delivery, student engagement, and assessment. J. Bus. Ethics 2014, 125, 513-529. [CrossRef]

29. Jarvis, R.M. The law school admiralty exam. J. Marit. Law Commer. 2014, 45, 97-117.

30. Al-yakoob, S.; Sherali, H.D.; Al-jazzaf, M. A mixed-integer mathematical modeling approach to exam timetabling. Comput. Manag. Sci. 2010, 7, 19-46. [CrossRef]

31. ProctorU. ProctorU celebrates delivering 4 million online proctored exams. PR Newswire, 25 September 2017.

32. Sánchez-Prieto, J.C.; Huang, F.; Olmos-Migueláñez, S.; García-Peñalvo, F.J.; Teo, T. Exploring the unknown: The effect of resistance to change and attachment on mobile adoption among secondary pre-service teachers. Br. J. Educ. Technol. 2019, 50, 2433-2449. [CrossRef]

33. Arteaga, R. Factores Motivacionales que Influyen en la Aceptación de las Redes Sociales Online Para Comunicarse con las Entidades Financieras. Ph.D. Thesis, Universidad de Huelva, Huelva, España, 2013.

34. Venkatesh, V.; Davis, F.D. A theoretical extension of the technology acceptance model: Four longitudinal field studies. Manag. Sci. 2000, 46, 186-204. [CrossRef]

35. Marakas, G.M.; Yi, M.Y.; Johnson, R.D. The multilevel and multifaceted character of computer self-efficacy: Toward clarification of the construct and an integrative framework for research. Inf. Syst. Res. 1998, 9, 129-163. [CrossRef]

36. Moore, G.C.; Benbasat, I. Development of an Instrument to Measure the Perceptions of Adopting an Information Technology Innovation. Inf. Syst. Res. 1991, 2, 192-222. [CrossRef]

37. Bandura, A. Self-efficacy Mechanism in Human Agency. Am. Psychol. 1982, 37, 122-147. [CrossRef]

38. Zolait, A.H.S.; Mattila, M.; Sulaiman, A. The effect of User's Informational-Based Readiness on innovation acceptance. Int. J. Bank Mark. 2009, 27, 76-100. [CrossRef]

39. Venkatesh, V.; Morris, M.G.; Davis, G.B.; Davis, F.D. User acceptance of information technology: Toward a unified view. MIS Q. 2003, 27, 425-478. [CrossRef]

40. Venkatesh, V.; Morris, M.G. Why Don't Men Ever Stop to Ask for Directions? Gender, Social Influence and their Role in Technology Acceptance and Usage Behavior. MIS Q. 2000, 24, 115-139. [CrossRef]

41. Thompson, R.L.; Higgins, C.A.; Howell, J.M. Personal Computing: Toward a Conceptual Model of Utilization. MIS Q. 1991, 15, 124-143. [CrossRef]

42. Dwyer, C. Digital relationships in the MySpace generation: Results from a qualitative study. In Proceedings of the 40th Hawaii International Conference on System Sciences (HICSS), Waikoloa, HI, USA, 3-6 January 2007; p. 19.

43. Dwyer, C.; Hiltz, S.; Passerini, K. Trust and privacy concern within social networking sites: A comparison of Facebook and MySpace. In Proceedings of the Thirteenth Americas Conference on Information Systems, Keystone, CO, USA, 10-12 August 2017; pp. 9-12.

44. Acquisti, A.; Gross, R. Imagined communities: Awareness, information sharing, and privacy on the Facebook. In International Workshop on Privacy Enhancing Technologies, Montréal, Canada; Springer: Berlin/Heidelberg, Germany, 2006; pp. 36-58.

45. Rogers, E.M. Diffusion of Innovations, 4th ed.; Collier Macmillan: New York, NY, USA, 1995.

46. Tan, M.; Teo, T.S.H. Factors influencing the adoption of Internet banking. J. Assoc. Inf. Syst. 2000, 1, 5. [CrossRef]

47. Davis, F.D.; Bagozzi, R.P.; Warshaw, P.R. User acceptance of computer technology: A comparison of two theoretical models. Manag. Sci. 1989, 35, 982-1003. [CrossRef]

48. Chiu, Y.B.; Lin, C.P.; Tang, L.L. Gender differs: Assessing a model of online purchase intentions in e-tail service. Int. J. Serv. Ind. Manag. 2005, 16, 416-435. [CrossRef] 
49. Nysveen, H.; Pedersen, P.; Thornbjørnsen, H. Intentions to use mobile services: Antecedents and cross-service comparisons. J. Acad. Mark. Sci. 2005, 33, 330-346. [CrossRef]

50. Muñoz, F. La adopción de una Innovación Basada en la Web. Análisis y Modelización de los Mecanismos Generadores de Confianza; Universidad de Granada: Granada, Spain, 2008.

51. Willis, T. An Evaluation of the Technology Acceptance Model as a Means of Understanding Online Social Networking Behavior; University of South Florida: Tampa, FL, USA, 2008.

52. Ajzen, I. The theory of planned behavior. Organ. Behav. Hum. Decis. Process 1991, 50, 179-211. [CrossRef]

53. Ajzen, I.; Fishbein, M. Understanding Attitudes and Predicting Social Behaviour; Prentice-Hall: Englewood Cliffs, NJ, USA, 1980.

54. Taylor, S.; Todd, P. Decomposition and cross over effects in the theory of planned behaviour: A study of consumer adoption intentions. Int. J. Res. Mark. 1995, 12, 137-155. [CrossRef]

55. Maridueña, M.R.; Leyva, M.; Febles, A. Modelado y análisis de indicadores de ciencia y tecnología mediante mapas cognitivos difusos. Cienc. De La Inf. 2016, 47, 17-24.

56. Papageorgiou, E.I.; Markinos, A.T.; Gemtos, T. Application of fuzzy cognitive maps for cotton yield management in precision farming. Expert Syst. Appl. 2009, 36, 12399-12413. [CrossRef]

57. Papageorgiou, E.I.; Salmerón, J.L. A Review of Fuzzy Cognitive Maps Research During the Last Decade. IEEE Trans. Fuzzy Syst. 2013, 21, 66-79. [CrossRef]

58. Curia, L.; Lavalle, A. Estrategias de decisión en sistemas dinámicos-Aplicando mapas cognitivos difusos aplicación a un ejemplo socio-económico. J. Inf. Syst. Technol. Manag. 2011, 8, 663-680. [CrossRef]

59. Codara, L. Le Mappe Cognitive; Carocci Editore: Roma, Italy, 1998.

60. Özesmi, U.; Özesmi, S.L. Ecological models based on people's knowledge: A multistep Fuzzy Cognitive Mapping approach. Ecol. Model. 2004, 176, 43-64. [CrossRef]

61. Solana Gutierrez, J.; Rincón Sanz, G.; Alonso González, C.; Garcia De Jalon Lastra, D. Utilización de Mapas de Conocimiento Difuso (MCD) en la asignación de prioridades de la restauración fluvial: Aplicación al río Esla. Cuad. De La Soc. Española De Cienc. For. 2015, 41, 367-380.

62. Mouratiadou, I.; Moran, D. Mapping public participation in the Water Framework Directive: A case study of the Pinios River Basin, Greece. Ecol. Econ. 2007, 62, 66-76. [CrossRef]

63. Banini, G.A.; Bearman, R.A. Application of fuzzy cognitive maps to factors affecting slurry rheology. Int. J. Miner. Process. 1998, 52, 233-244. [CrossRef]

64. FCMappers. Available online: http://www.fcmappers.net (accessed on 15 February 2020).

65. Özesmi, U.; Özesmi, S.L. A participatory approach to ecosystem conservation: Fuzzy cognitive maps and stakeholder group analysis in Uluabat Lake, Turkey. Environ. Manag. 2003, 31, 0518-0531. [CrossRef] [PubMed]

66. Howlett, B.; Hewett, B. Securing and proctoring online tests. In Online Assessment and Measurement: Foundations and Challenges; IGI Global: Hershey, PA, USA, 2005; pp. 300-329.

67. Sutton, H. Minimize online cheating through proctoring, consequences. Recruit. Retaining Adult Learn. 2019, 21, 1-5. [CrossRef]

68. Bandyopadhyay, K.; Barnes, C.; Bandyopadhyay, S. An investigation of the factors that influence the use of proctoring in online courses. In Proceedings of the Association of Collegiate Marketing Educators (2015); ACME: Prairie View, TX, USA, 2015; pp. 49-50.

69. Atoum, Y.; Chen, L.; Liu, A.X.; Hsu, S.D.; Liu, X. Automated online exam proctoring. IEEE Trans. Multimed. 2017, 19, 1609-1624. [CrossRef]

70. Davis, A.B.; Rand, R.; Seay, R. Remote proctoring: The effect of proctoring on grades. In Advances in Accounting Education: Teaching and Curriculum Innovations; Emerald Group Publishing Limited: Bingley, UK, 2016; pp. 23-50.

71. OReilly, G.; Creagh, J. A categorization of online proctoring. In Global Learn; Association for the Advancement of Computing in Education (AACE): Jacksonville, FL, USA, 2016; pp. 542-552.

72. Kayser, M.N. Online Proctoring Success Factors E Best Practices; Minnesota eLearning Summit: Saint Paul, MN, USA, 2016.

(C) 2020 by the authors. Licensee MDPI, Basel, Switzerland. This article is an open access article distributed under the terms and conditions of the Creative Commons Attribution (CC BY) license (http://creativecommons.org/licenses/by/4.0/). 